\title{
IMPACT OF FISCAL DECENTRALIZATION ON MOTOR VEHICLE TAXATION IN THE SLOVAK REPUBLIC
}

\author{
Vladimír Konečny' ${ }^{1}$, Jozef Gnap ${ }^{2}$ Ivana Šimková ${ }^{3}$ \\ University of Žilina, Faculty of Operation and Economics of Transport and Communications, \\ Department of Road and Urban Transport \\ Univerzitná 1, 01026 Žilina, Slovakia, \\ e-mail addresses: ${ }^{1}$ vladimir.konecny@fpedas.uniza.sk, ${ }^{2}$ jozef.gnap@fpedas.uniza.sk, \\ 3ivana.simkova@fpedas.uniza.sk
}

\begin{abstract}
The article deals with the motor vehicle tax in relation with fiscal decentralization, particularly from 2005 with competence delegated to the self-governing regions in the area of motor vehicle tax. The result of this provision in the field of fiscal decentralization is increasing of differences in the motor vehicle tax burden in self-governing regions of Slovakia. The paper is the result of solving a series of impact studies solved by the authors in this field. Gradually over time from the transfer of competences in setting tax rates on motor vehicles to self-governing regions and usage of the incomes of this tax can realistically assess the development and impact of this element of fiscal decentralization in the Slovak Republic as well as propose a solution of resulting situation. The aim is to eliminate differences in motor vehicle tax burden at regional and interstate level while maintaining the current level of tax revenues of self-governing regions.
\end{abstract}

Keywords: taxation, motor vehicle tax, tax rates, fiscal decentralization, motor vehicle, self-governing region

\section{Introduction}

Fiscal decentralization is presented as a tool for increasing the efficiency and transparency in the provision of public services (Oates, 1972). The reason for its implementation, are the facts that the self governing region has a better position to ensure the provision of public services due to the proximity to people and knowledge of local specificities as well as ways to better inform people in comparison with the central government (Rodríguez-Pose et al., 2009, Aristovnik, 2012).

Fiscal decentralization represents a part of the reform of public authority in Slovakia. Between 2002 and 2004 was a period when more than 400 competencies were transferred from government authorities to self - governing regions under the decentralization of public authorities. The transfer was carried out in accordance with the approved law 416/2001 collection of laws, about the transfer of some competencies from government authority to municipality and public authorities in 5 years (up to 1.1.2002, 1.4.2002, 1.7.2002, 1.1.2003, 1.1.2004), (Pétrová 2007).

Since 1st of January 2005 was approved a new system of financing in municipalities and public authorities (II. Stage of fiscal decentralization), which strengthened their autonomy and accountability with using public funds to provide services to the citizens. Economic heart of this process was to strengthen tax revenues of municipalities and public authorities at the expense providing subsidies from the state budget to self - governing regions. The fiscal decentralization follows at the previous transfer of competencies from government authorities to municipalities and public authorities according to law 416/2001 collection of laws, about the transfer of some competencies from government authority to municipality and public authorities and about the amendment of certain laws. To achieve the objectives of fiscal decentralization it was necessary to adopt new legislations. In September 2004, there were adopted four laws:

- Law no. 523/2004 collection of laws, about budget rules of public authority

- Law no. 583/2004 collection of laws, about budget rules of self - governing regions

- Law no. 582/2004 collection of laws, about local taxes and local fees for municipal waste and minor construction waste

- Law no. 564/2004 collection of laws, about budgetary determination of income tax revenues of self - governing regions and in December 2004 was adopted government regulation of Slovakia no. 668/2004 collection of laws, about distribution of income tax revenues of self - governing regions with effect from 1st January 2005 (Kozovský et al., 2009).

To strengthen the financial autonomy in self - governing regions from the state budget similarly as in other countries, e.g. Switzerland (Feld, 2003) was an important objective of decentralization in Slovakia. 
The risks of fiscal decentralization were characteristics that were associated with regional differences in Slovakia (Neupauerová, 2008).

This article deals with fiscal decentralization in Slovakia in relation to tax on motor vehicles like a source of tax revenue self - governing regions. The motor vehicle tax was adopted in 2005 in Slovakia by law no. 582/2004 collection of laws, about local taxes and local fees for municipal waste and minor construction waste. The tax is a direct property tax and the tax facultative within the tax system of Slovakia. Self - governing regions have the option of introducing a tax on motor vehicles, to determine the tax rate and the scope of the exemptions.

According to Nižňanský and Valentovič (2002), desirable assumptions from implementing fiscal decentralization include also the tax jurisdiction, which is able to affect a significant proportion of income increase of a community, and a certain degree of freedom in deciding on budgeting and setting tax rates. Self - governing regions obtain the "tax freedom" thanks to decentralization and since 2005 they may set the tax rate of motor vehicles in the form of generally binding regulations. Financial Directorate of Slovakia is the tax authorities, which distribute revenues from taxes between eight regions. Production factors of road freight transport organizations, which are mainly vehicles and drivers; they are not statically bound to a specific location; they are constantly in motion and they use a common national and transnational road infrastructure for a transformation process. This tax freedom and the differences of tax rates cause nonuniformity on the domestic and international road transport market. Demand for transport service is the secondary demand; it is influenced by the level of company demand and individuals for goods and services. The decline in production and decreasing demand for goods and service during the financial and economic crisis significantly determines the performance of the road transport sector. Performance of road freight transport was reduced after 2008 in Slovakia. The quantity of transported goods decreased by $18 \%$ in 2009 compared to 2008. The decline continued in the following years, there was decreased by $33.7 \%$ in 2012 compared to the year 2008. Information is based on yearbook of transport, posts and telecommunications in Slovakia.

Raising rates of motor vehicles tax affects the sustainability of business in the road transport sector, which affects employment and also a government revenue in the personal income tax and corporation tax. Motor vehicle tax is a direct cost of carrier; with a declining volume performance of carrier, it increases the unit costs and the price of transport (e.g. Gnap, 2006). That has an impact on the competitiveness of Slovak carriers; especially compared to carriers from neighboring EU countries that pay less motor vehicles tax; and that can perform partly national transport in Slovakia.

Nižňanský and Valentovič (2002) state that there are no reason to have any concerns about the deepening of regional disparities in the case of application of tax differentiation. The fact after the introduction of fiscal decentralization is significantly different; it has been confirmed by research (Gnap et al., 2007, 2010, 2012) and analysis in this area (e. g. Masaryk, 2014).

Different level of rates of motor vehicles tax affects by different ways the cost level of road carriers and their competitiveness in area of sustainability costs and pricing in different regions. Frequent changes in tax rates by the government destabilize the business environment and create an uncertain environment. On the base of a pressure of association of carriers Slovak Republic, mainly association of road transport operators of the Slovak Republic (ČESMAD Slovakia) and union of road transport operators of the Slovak Republic; in 2014, the Ministry of Finance of the Slovak Republic has undertaken to prepare the Law of motor vehicles tax.

\section{The motor vehicles tax in the concept of tax reform from 2004 to 2006 in Slovakia}

According to the concept of tax reform, the objective of the new law of motor vehicles tax was the creation of a legal basis for taxation only of commercial vehicles according to the concept of tax reform. Law of motor vehicles tax would have replaced the existing law, which was focused on the taxation of passenger vehicles and commercial vehicles that are used for business.

The concept of tax reform in relation to motor vehicles tax contained several important objectives:

- Objective 1: taxation of all commercial vehicles regardless of their use

- Objective 2: take account of environmental load by the amount of emissions in the form of tax relief

- Objective 3: tax does not include an exemption (except for vehicles of diplomatic missions and consular posts, if reciprocity is guaranteed)

The concept of motor vehicle tax in terms of reform was in conflict with the concept of fiscal decentralization. The aim was on one hand reduce the number of vehicle taxations about passenger cars and buses and also reduce tax rates for commercial vehicles, which significantly exceed (and currently still 
exceed), according to the minimum tax rates under Annex I of Directive 1999 / 62 / EC Minimum tax rates applicable to vehicles. The motor vehicle tax rate exceeded the minimum rate of tax according to the directive 1999/62 / EC to 3.7 times, before the application the law of motor vehicle tax. On the other hand; the concept of fiscal decentralization assumed receipts from motor vehicles tax at level of 82.98 million euros (2.5 billion. SKK) in the financing of autonomous regions since 2005 , which follows continuously on road tax in 2004, which stood at level of 81.86 million of euros (2.466 billion. SKK), (Tax Directorate of the Slovak Republic, 2004). Lowering of tax rates and the number of vehicle taxations would be contrary with tax receipts of self - governing regions.

\section{The motor vehicles tax - objectives of the concept of tax reform in Slovakia and the current state}

In the concept of tax reform it was considered to abolish of road tax and introduction motor vehicles tax. The commercial motor vehicles regardless of their use would become the subject of tax and the taxation of motor vehicles and buses would be abolished. No changes have been made in this area in 2004. It can be said that only the name of the tax was changed from road tax to the motor vehicle tax and principles and scope of taxation remained almost unchanged. From the names of taxes it could be assumed that the road tax is a tax related to the use of road infrastructure and the motor vehicle tax is a tax related to the ownership of vehicle. Name of the tax could be "vehicle tax for business". Taxation of trucks is more related to ensuring the current level of government revenues in self - governing regions (after fiscal decentralization), than with explanation of the tax on an economic base. The ownership principle cannot be clearly applied in the case of commercial vehicles, as a bus or truck is very likely to be used primarily for business or other specific activities. The ownership principle cannot be clearly applied in the case of commercial vehicles as a bus or a truck; it is very likely that the vehicles are used primarily for business or other specific activities. Taxation of these vehicles is an indirect form of income taxation (Sporina, 2012). (Gravena 2011, 2012)Vehicle taxation occurs in the form of registration or circulation taxes in the world. Registration tax is a tax that is paid one-time in case of the first registration of a vehicle. The subject of the tax is the vehicle. In connection with a circulation of tax; the following methods of taxation are applied abroad (Graven (2012), OECD (2012), Barbour (2009)):

- vehicle tax is a taxation of registered motor vehicles regardless of their use and the way of ownership; tax is usually paid once per year

- road tax is a tax that must be paid in connection with the use of motor vehicle on public roads. The subject of the tax is the vehicle but the vehicle has to be used on public road infrastructure. This is not a fee for the use of road infrastructure in the form of tolls.

The road tax and vehicle tax are circulation taxes that are usually paid once per year. In Slovakia, based on law no. 582/2004 collection of laws, about local taxes and local fees for municipal waste and minor construction waste; the self - governing regions may impose a motor vehicles tax in generally binding regulations (GBR). They include annual tax rates separately for passenger cars and commercial vehicles. Tax rates are different between regions. Regions may also define a rate of benefits for vehicles and a scope of the tax exemptions. The subject of the tax is the vehicle and trailer category M, N, O that is registered in the Slovak Republic and is used for business.

The current legislation discriminates against entrepreneurs at the expense of other owners of vehicles. There is no economic justification for the payment of motor vehicle tax only by legal persons and entrepreneurs. On the other hand, the universal application of the current motor vehicle tax rates for all registered passenger vehicles would have an extremely negative effect especially at low-income groups in Slovakia (Sporina, 2012).

\section{Motor vehicle tax rates in Slovakia and their changes}

During the introduction of the motor vehicles tax, all self - governing regions set tax rates for 2005 by relevant generally binding regulations; six of the eight self - governing regions introduced the same tax rates. Self - governing regions introduced the same rates road tax as in 2004. In 2005, selected regions used their competence and adopted generally binding regulations to increase tax rates for 2006 . In the period 2005-2013, Nitra region (NR), Trenčín region (TN) and Trnava region(TT) (4 changes) adopted the largest number of changes in tax rates, Košice (KE) and Prešov (PO) region (2 changes), minimum changes was adopted in Bratislava region (BA). 
This development is unsustainable in the future, because changes in tax rates are inconsistent, uneven and non-conceptual. The result of the concept is growth of tax rates. For a period of nine years the tax rate increased the most in Trnava region $(+33.5 \%)$ and Bratislava region $(+26.5 \%)$. The smallest increase was in Trenčín region $(+8.2 \%)$. The diversity of tax rates and scope of the exemptions are discriminatory, those regional differences are continually increasing. The diversity of tax rates and scope of the exemptions are discriminatory, those regional differences are continually increasing. Business subjects often conduct activities in the common areas and common road infrastructure, irrespective of the territorial affiliation. The differences are continuously growing since the introduction of taxes (in 2005). This development greatly affects the costs of carriers and their level of competitiveness at national and international levels. The average difference of the basic tax rates between regions with the lowest and the highest tax rates represent up to 8.2\% in 2014 (refers to Bratislava region and Banská Bystrica region). The largest average difference of tax rates is $23.4 \%$; between the basic tax rate in Bratislava region and the tax rate for green vehicles meeting the Euro 4 emission limits and more in Trenčín region.

Figure 1 shows the evolution of annual tax rates of semi-trailer truck with a total weight of 40 tons in the regions of Slovakia, the tractor meets Euro 4 limits. This is the most common type of vehicles combination in national and international road freight transport (Konečný, 2013). The maximum difference of the annual tax for semi-trailer truck between the regions represents value of 454 euros in 2014.

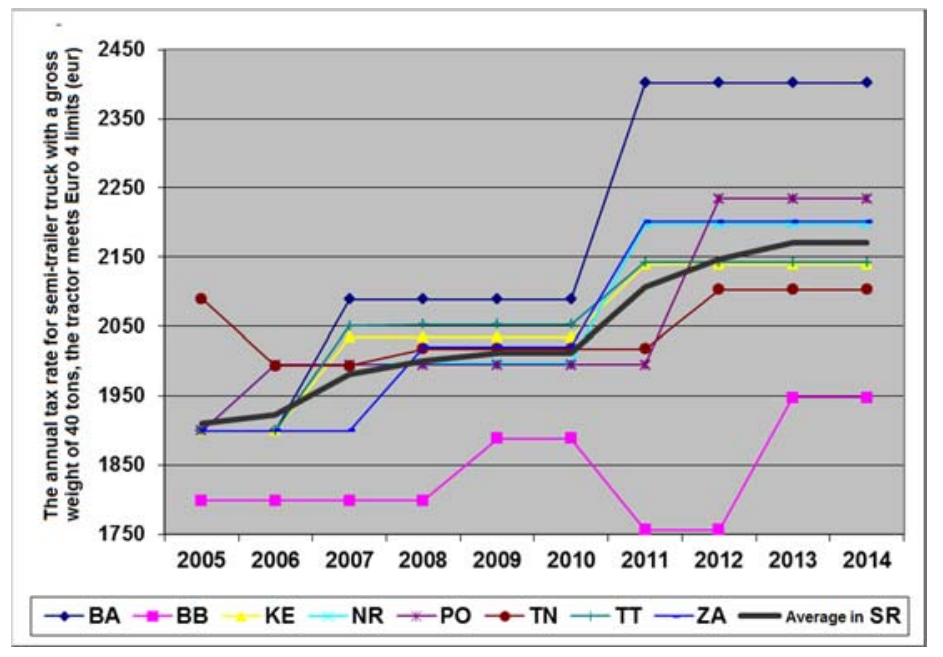

Figure 1. Development of the annual tax rate for semi-trailer truck in Slovakia

\subsection{Possibilities of tax reductions for green vehicles}

According to tax reform for 2004-2006 it is possible to take into account the environmental burden by the amount of emissions in the form of tax relief. For this purpose there is the emission limits rule $E H K$ OSN no. 49 Emissions from diesel and spark ignition engines. This regulation establishes maximum levels of selected pollutants from exhaust of diesel engines. Emission limits come into force gradually and it is coming with stricter conditions. Newly registered commercial vehicles must meet those limits. In 2009 entered into force on Euro 5 emission limits and in 2013 entered into force on Euro 6 emission limits.

The current system of vehicle taxation applies a benefit for green vehicles. Tax rates are different between regions. The rate preferential treatment of vehicles and scope of the exemptions are on the regions. It creates conditions for non-application of benefits for green vehicles and creates an uneven playing field for business in terms of tax burden.

The development of preference for green vehicles by reduced tax rate is slow. When introducing of motor vehicle tax in 2005 only Banská Bystrica region (BB) applied it; in 2014, 6 of 8 regions applied it too (except the Bratislava and Prešov). The average benefit by reduced tax rate for Euro 3 is $4.2 \%$, the average benefit for the Euro 4 vehicles and more is $8 \%$. The rate of benefits is different in each region. Figure 2 shows a comparison of average differences of motor vehicle tax rates for commercial vehicles and the basic rates. The differences are expressed in percentages for the year 2014. The figure 2 also includes the average benefit in Slovakia. 


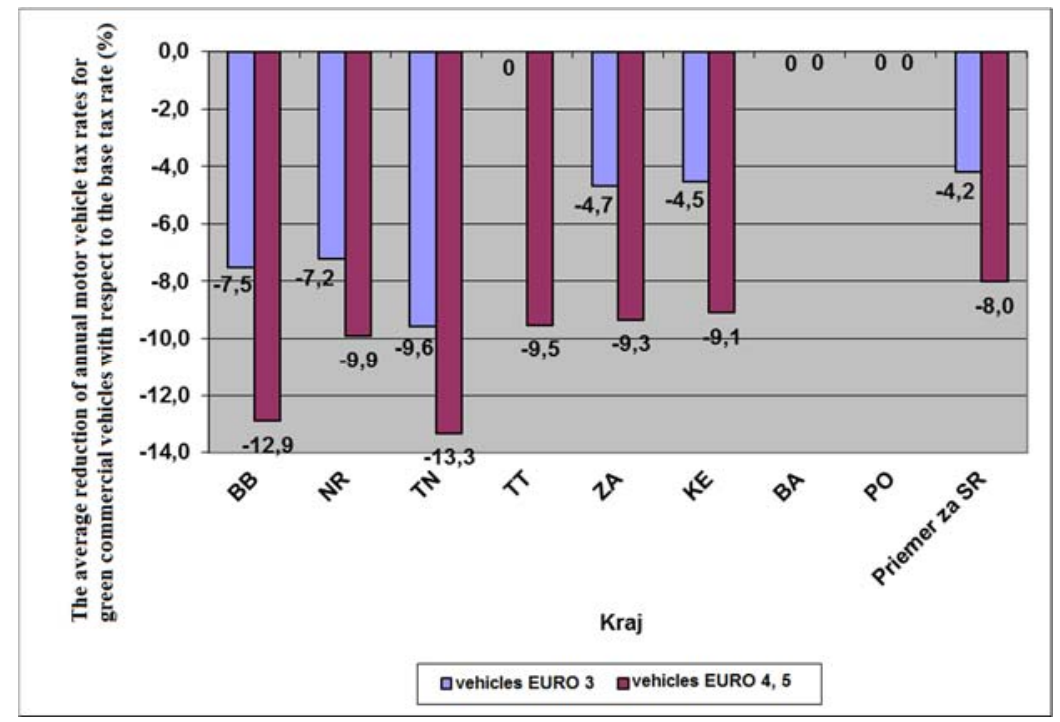

Figure 2. The average reduction of annual motor vehicle tax rates for green commercial vehicles with respect to the base tax rate for $2014^{1}$ in other areas.

Energy efficiency of transport and its direction is limited by the national strategies and action plans

Under measure 6.7 Modernizing of the fleet by document "Action Plan of Energy Efficiency for the years 2008-2010 in the transport sector" was defined this measure: improving the energy efficiency of vehicles - change in tax structure for motor vehicles, handicap of older vehicles - scrappage. Energy savings associated with this measure was achieved by introducing the scrappage.

There has been no change in the structure of motor vehicle tax at the time of implementation of the Action Plan. Specific measure of this kind was not included in the next Action Plan of Energy Efficiency For 2011 to 2013. In many European countries is applied significantly higher level of benefits for green vehicles compared to Slovakia; for example in Czech Republic, Hungary, Germany and United Kingdom.

Long term vision of development of Slovakia is also speed up replacement of obsolete vehicle fleet with new vehicles that meeting the emission limits of Euro 4 and above. Regional disproportions occur also in exemptions, some exemptions are applied in several regions (vehicles of self - governing regions, vehicles of diplomatic missions and consular offices), and others are specific to a particular region.

The aim of the tax reform concept from 2004 to 2006 was the elimination of exemptions, which the current system of vehicle taxation does not respect. State also came on one of the tools internalisation of external transport costs and obligations arising from the White Book; Plan for the single European Transport Area - Towards a competitive transport system that is resource-efficient.

\section{Revenue from motor vehicles taxes and selected expenses of self-governing regions}

The expenditure self- governing regions have a long-term increasing trend. The most important part of the resources for their coverage is the revenue from motor vehicle tax. In 2005, tax revenues of regions were of 23.9\% (Šimoňáková, 2011), in 2011 it was $24.4 \%$ in 2012 already $25.1 \%$. Tax revenue was not reduced when the road tax was replaced by the motor vehicles tax; followed the road tax and continuously increased. In 2002, tax revenue reached 76.58 million EUR (2,307 bn.SKK); in 2003 it was 78.9 million EUR (2.377 bn. SKK) and in 2004 already 81.86 million EUR ( 2.466 bn. SKK). The real tax revenues of self-governing regions are higher than the planned revenue before decentralization, table 1.

${ }^{1}$ The average of Slovakia includes two regions that do not support green vehicles in 2014 (Bratislava, Prešov) 
Table 1. Planned and actual tax revenues of self- governing regions before and after fiscal decentralization (million EUR) ${ }^{2}$

\begin{tabular}{|c|c|c|c|c|c|c|c|c|}
\hline $\begin{array}{l}\text { The plan of tax } \\
\text { revenue before } \\
\text { decentralization: }\end{array}$ & 2005 & 2006 & 2007 & 2008 & 2009 & 2010 & 2011 & 2012 \\
\hline Motor vehicle tax & $\begin{array}{c}82,98^{2} * \\
(2500 \\
\text { SKK) }\end{array}$ & $\begin{array}{l}84,65 * \\
(2550 \\
\text { SKK) }\end{array}$ & $\begin{array}{l}86,31 * \\
(2600 \\
\text { SKK })\end{array}$ & $\begin{array}{l}87,96 * \\
(2650 \\
\text { SKK) }\end{array}$ & - & - & - & - \\
\hline $\begin{array}{l}\text { Total tax } \\
\text { revenues of } \\
\text { public authorities }\end{array}$ & $\begin{array}{c}352,72 * \\
(10626 \\
\text { SKK })\end{array}$ & $\begin{array}{c}379,51 * \\
(11433 \\
\text { SKK) }\end{array}$ & $\begin{array}{c}411,17 * \\
(12387 \\
\text { SKK })\end{array}$ & $\begin{array}{c}447,16 * \\
(13471 \\
\text { SKK })\end{array}$ & - & - & - & - \\
\hline \multicolumn{9}{|l|}{$\begin{array}{l}\text { The actual tax } \\
\text { revenues after } \\
\text { decentralization: }\end{array}$} \\
\hline $\begin{array}{l}\text { Motor vehicle } \\
\text { tax }\end{array}$ & 92,92 & 102,62 & 117,76 & 80,15 & 125,82 & 118,61 & 125,09 & 134,62 \\
\hline $\begin{array}{l}\text { Income tax of } \\
\text { natural persons }\end{array}$ & 295,31 & 334,83 & 359,94 & 428,21 & 403,48 & 332,82 & 386,55 & 401,10 \\
\hline $\begin{array}{l}\text { Total tax } \\
\text { revenues of } \\
\text { public } \\
\text { authorities }\end{array}$ & 388,23 & 437,45 & 477,7 & 508,36 & 529,3 & 451,43 & 511,64 & 535,72 \\
\hline \multicolumn{9}{|l|}{$\begin{array}{l}\text { Difference of } \\
\text { actual and } \\
\text { projected state }\end{array}$} \\
\hline $\begin{array}{l}\text { Motor vehicle } \\
\text { tax }\end{array}$ & 9,94 & 17,97 & 31,45 & $-7,81$ & - & - & - & - \\
\hline $\begin{array}{l}\text { Total tax } \\
\text { revenues of } \\
\text { public } \\
\text { authorities }\end{array}$ & 35,51 & 57,94 & 66,53 & 61,2 & - & - & - & - \\
\hline
\end{tabular}

The motor vehicle tax is presented as a tax that is administered by public authorities. This connection of legislation has not been modified. The motor vehicle tax is the revenue source without further specified purpose and the road infrastructure is reflected on the distribution of revenue tax natural person income in the public authorities. In this context, the legitimacy of tax administration is questionable at the local level (Sporina, 2012). This is supported by the Nižn̆anský (2005), which states that the financing of public authorities competencies will be used revenue from motor vehicles tax by territory. Self-governing regions do not manage this tax. They do not have any vehicle register; not have any control activities in payment of that tax by businesses in the region.

At present, between experts and public road transport sector resonates an issue of earmarking of revenue from motor vehicles tax, respectively use a part of revenue for maintenance and repair regional roads II. and III. classes, which are owned by self- governing regions. The issue is caused by the differences in expenditure of self- governing regions in road infrastructure; including of significant differences in the number of kilometers of managed communications and difficult maintenance in different regions of Slovakia; that confirmed expert study (Gnap et al., 2012).

This situation escalated after effort of implementation a prohibition of driving for trucks over 12 tons of total weight on all roads II. and III. class. Carriers point out that they have to pay the tax to self governing regions and they forbid operating of carriers vehicles on the roads, which are in their administration. Within the project Centre of Excellence for systems and intelligent transport was found that some road haulage operators of Slovak would take the introduction of electronic toll collection on the road II. and III. class but they would not pay motor vehicles tax and they would not introduction the prohibition of driving for trucks.

Collection of the tax by individual regions is determined by economic development of the region and the attractiveness of the business environment. These factors create the potential for increasing demand for road transport services, which is reflected by the growth performance of vehicles and these factors increase especially number of vehicles operated that is subject to tax in relation to income from motor vehicles tax.

\footnotetext{
${ }^{2}$ Planned value of tax revenues for the year 2005 to 2008 where the exchange rate was 1 EUR $=30.1260$ SKK from SKK to EUR

* prognosis before the introduction of fiscal decentralization; prognosis was prepared for the period 2005-2008
} 
The disparities in tax revenues of regions are caused by tax competence of self- governing regions and frequent changes in tax rates, figure 3.

The increase in tax collection is caused by the increasing number of taxpayers of motor vehicles tax and no by growth of the average tax rates. After adjustment of the tax from a variable number of taxpayers, the collection of taxes should have a declining trend, table 2 .

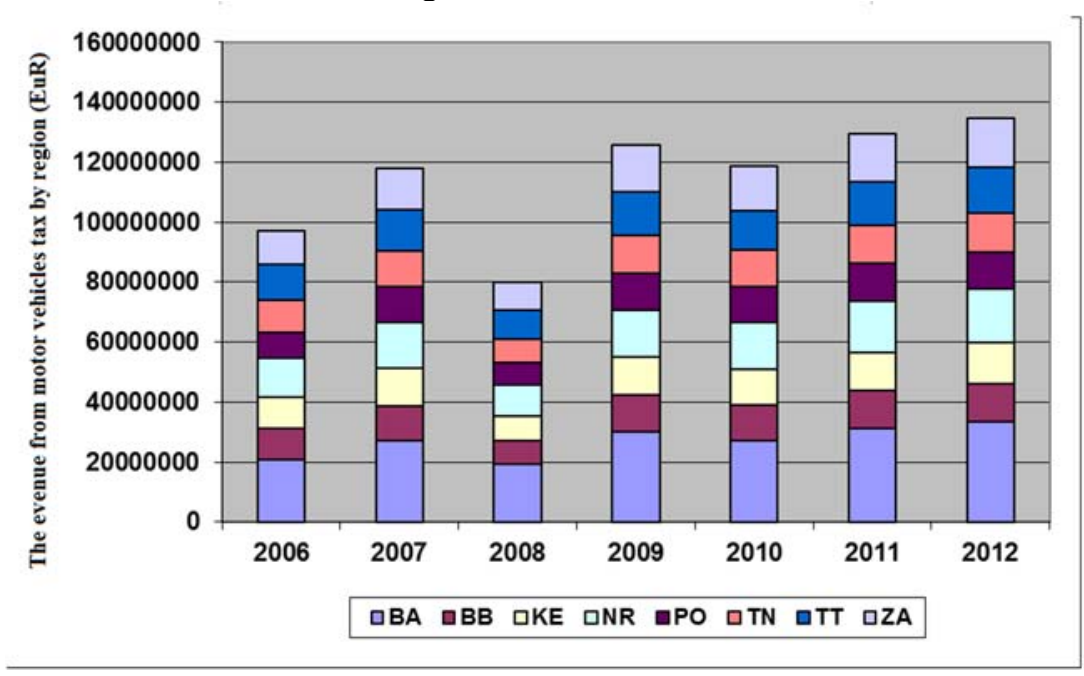

Figure 3. Revenue from taxes of motor vehicles by region (EUR)

Table 2. Development of characteristics related to the motor vehicles $\operatorname{tax}^{3}$

\begin{tabular}{|c|c|c|c|c|c|c|c|c|c|}
\hline & 2005 & 2006 & 2007 & 2008 & 2009 & 2010 & 2011 & 2012 & 2013 \\
\hline \multicolumn{10}{|l|}{ Taxpayers } \\
\hline $\begin{array}{l}\text { Number of } \\
\text { taxpayers for } \\
\text { motor vehicles tax }\end{array}$ & 172735 & 206535 & 236091 & 261506 & 296828 & 322295 & 348638 & 358468 & 368573 \\
\hline $\begin{array}{l}\text { The growth rate of } \\
\text { the number of } \\
\text { taxpayers (-) }\end{array}$ & 1,000 & 1,196 & 1,367 & 1,514 & 1,718 & 1,866 & 2,018 & 2,075 & 2,134 \\
\hline \multicolumn{10}{|l|}{ Tax rates } \\
\hline $\begin{array}{l}\text { The growth rate of } \\
\text { average tax rates } \\
(-)\end{array}$ & 1,000 & 1,007 & 1,036 & 1,115 & 1,122 & 1,122 & 1,234 & 1,250 & 1,259 \\
\hline \multicolumn{10}{|l|}{ Tax collection } \\
\hline $\begin{array}{l}\text { Motor vehicles } \\
\text { tax collection in } \\
\text { individual years } \\
\text { (mil. eur) }\end{array}$ & 92,92 & 102,62 & 117,76 & 80,15 & 125,82 & 118,61 & 125,09 & 134,62 & 141,6 \\
\hline $\begin{array}{l}\text { The growth rate of } \\
\text { tax collection (-) }\end{array}$ & 1,000 & 1,104 & 1,267 & 0,863 & 1,354 & 1,276 & 1,346 & 1,449 & 1,524 \\
\hline $\begin{array}{l}\text { The growth rate of } \\
\text { tax collection } \\
\text { adjusted by the } \\
\text { growth in the } \\
\text { number of } \\
\text { taxpayers of } \\
\text { motor vehicles tax }\end{array}$ & 1,000 & 0,924 & 0,927 & 0,570 & 0,788 & 0,684 & 0,667 & 0,698 & 0,714 \\
\hline
\end{tabular}

Carriers for payment of motor vehicles tax to the budgets of self-governing regions expect the possibility of usage of good and maintained road infrastructure mainly in national transport for the distribution of goods at regional and local level in return.

The share of ordinary expenditures of regions on road communications $(€ / \mathrm{km})$ reaches across regions significantly different values. Expenditures of regions into the road infrastructure are markedly limited by different length of managed road infrastructure. The smallest length of infrastructure is managed

\footnotetext{
${ }^{3}$ The table does not include the development of tax rates for each year in absolute terms because of the differences in tax calculation for individual groups of vehicles.
} 
by the self - governing region of Bratislava. This situation has been typical since 2005 when motor vehicles tax was introduced, see table 3.

Table 3. Tax revenue and ordinary expenditures of regions on public transport and road communications in 2012

\begin{tabular}{|c|c|c|c|c|c|c|c|c|}
\hline \multirow[b]{2}{*}{ Region } & \multicolumn{3}{|c|}{ Tax revenue $(€)$} & \multicolumn{3}{|c|}{$\begin{array}{l}\text { Ordinary expenditures on public transport } \\
\text { and communications }(€)\end{array}$} & \multirow[b]{2}{*}{$\begin{array}{l}\text { Commu- } \\
\text { nications } \\
\text { owned by } \\
\text { the region } \\
\text { (km) }\end{array}$} & \multirow[b]{2}{*}{$\begin{array}{c}\text { Ordinary } \\
\text { expendi- } \\
\text { tures on } \\
1 \text { km of } \\
\text { communi- } \\
\text { cations } \\
(€ / \mathbf{k m})\end{array}$} \\
\hline & $\begin{array}{c}\text { Personal } \\
\text { entity } \\
\text { income tax }\end{array}$ & $\begin{array}{c}\text { Motor } \\
\text { vehicles tax }\end{array}$ & Overall & $\begin{array}{l}\text { Ordinary } \\
\text { expenditu- } \\
\text { res on } \\
\text { public } \\
\text { transport }\end{array}$ & $\begin{array}{c}\text { Ordinary } \\
\text { expenditures } \\
\text { on } \\
\text { communica- } \\
\text { tions }\end{array}$ & $\begin{array}{l}\text { Ordinary } \\
\text { expenditures } \\
\text { on public } \\
\text { transport and } \\
\text { communica- } \\
\text { tions overall }\end{array}$ & & \\
\hline $\mathrm{BA}$ & 32416385 & 33346130 & 65762515 & 8034381 & 8273593 & 16307974 & 564 & 14770 \\
\hline $\mathrm{BB}$ & 59831658 & 12619602 & 72451260 & 19285807 & 11575182 & 30860989 & 2463 & 4700 \\
\hline $\mathrm{KE}$ & 55395826 & 12296526 & 67692349 & 15954988 & 12292391 & 28247379 & 2007 & 6125 \\
\hline NR & 53950987 & 18026543 & 71977530 & 15626125 & 11098223 & 26724348 & 2041 & 5438 \\
\hline $\mathrm{PO}$ & 63702677 & 13839598 & 77542275 & 20375518 & 14929734 & 35305252 & 2445 & 6106 \\
\hline
\end{tabular}

The share of road freight and bus transport on tax collection is crucial since along with trailers it usually makes up for more than $70 \%$ of the tax collection.

\section{Reasons and unification options for motor vehicles tax rates in Slovakia}

The revenue from the motor vehicles tax is an income for the budget of self - governing region in which territory the vehicle is registered. The solution may be an enforcement of the obligation for regional vehicle registration based on the place of use of motor vehicles for business purposes.

Such a solution has not been enforced yet. Risks defined by the Ministry of Finance of the Slovak republic before transferring tax powers onto self-governing regions in 2004 were confirmed. The biggest disparities in the tax collection from motor vehicles are between the self-governing region of Bratislava and other self-governing regions. These contrasts are caused not only by the differences in tax rates, but also by the number of taxpayers and tax subjects. This situation encourages efforts to design and implement an uniform system for motor vehicles tax collection with uniform rates and criteria for redistribution of revenue between the self-governing regions similarly to the principles used in shared taxes of the personal entity income tax. This would result in the elimination of existing differences in the system of motor vehicle taxation.

The redistribution system of motor vehicles tax revenue must comply with the financial demands of different self-governing regions while securing activities such as suburban bus transport services, management and maintenance of II. and III. class roads, regional educational system, regional health service, social issues and culture (Kozovský et al., 2009).

The interannual growth of tax revenues from the motor vehicles tax in Slovakia is ensured by annual growth of tax rates, but mainly by an annual growth in number of taxpayers. The slowdown of growth in the number of taxpayers due to the slowdown in economic growth may jeopardize the tax revenues of self - governing regions.

The discrepancy between the sources of public budgets and the need for these resources can be solved by extension of tax and contribution bases (Šikula et al., 2008). Vehicles are the base in motor vehicles tax. Extending the scope of taxation on all registered vehicles, regardless of their intended use either for business or private purposes promotes securing resources for budgets of self-governing regions. Differences in the number of registered and taxable vehicles are increasing in Slovakia. Taxation of all the vehicles registered, including passenger automobiles is applied for example in Bulgaria, Belgium, Finland, France, Greece, Germany and Portugal. In European countries a central method of defining tax rate dominates over the regional. Regional method is applied for example in the Netherlands, Poland, Portugal and Italy. Greven (2012).

Extending the scope of taxation may create space for a reduction in the tax rates currently applied in the Slovak republic. These are among the highest in Europe. They are four times higher than the recommended minimum rate level set in EU legislation, figure 4. 


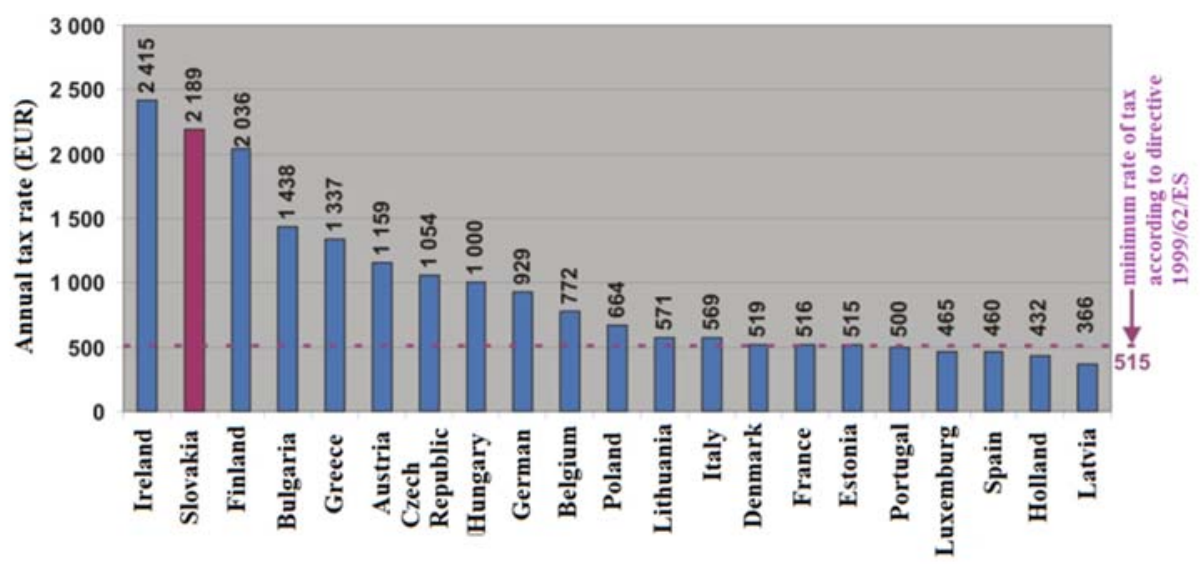

Figure 4. The annual tax rates for articulated vehicle with a gross weight of 40 tones in selected EU countries in 2012

After the introduction of electronic toll system charges for the use of road infrastructure a reduction in the rates of the motor vehicles tax occurred in selected European countries because of the weakened impact on the expenses of national road carriers, for example in Germany. An electronic toll was introduced in Slovakia on 1 January 2010, but the reduction of motor vehicles tax rates did not occur. The tax rate from 2009 remained in 2010. However, in the following years, they grew again. The condition for the unification of tax rates by the self-governing regions is to ensure a minimum level of tax revenue at the current level.

In order to ensure that the new draft of uniform rates will provide at least the same amount collected from the motor vehicles tax as the current system of taxation and application of 8 different tax rates by self - governing regions, this formula must be applied (1):

collection of taxes using uniform tax rates $\geq$ collection of taxes using current tax rates

$$
\sum_{i=1}^{n}\left(E_{4 i} . S_{4 i}+E_{3 i} . S_{3 i}+O V_{i} . S N_{2 i}+V_{p r e d 1990 i} . S N_{1 i}\right) \geq \sum_{j=1}^{8} \sum_{i=1}^{n}\left(E_{4 i j} . S_{3 i j}+E_{3 i j} . S_{2 i j}+O_{i j} . S_{1 i j}\right)
$$

Note: In the regions which do not apply preference of more ecological vehicles by lowering tax rates, only one rate $S 1 i$ will be applied and all vehicles will be assigned to the Oi group.

Where:

$\mathrm{E}_{4 \mathrm{i}}$ - number of Euro 4 (or more) taxable vehicles belonging to the i-th weight class

$\mathrm{E}_{3 \mathrm{i}}$ - number of Euro 3 taxable vehicles belonging to the i-th weight class

$\mathrm{OV}_{\mathrm{i}}$ - number of other taxable vehicles, not meeting Euro 3 (and more) emission limits and before 1990 belonging to the i-th weight class

$\mathrm{V}_{\text {pred1990i }}$ - number of taxable vehicles, $1^{\text {st }}$ time registered before 1990 belonging to the $\mathrm{i}$-th weight class $\mathrm{SN}_{4 \mathrm{i}}$ - uniform tax rate for the Slovak republic for the i-th weight class for Euro 4 (and more) vehicle

$\mathrm{SN}_{3 \mathrm{i}}$ - uniform tax rate for the Slovak republic for the i-th the weight class for Euro 3 vehicle

$\mathrm{SN}_{2 \mathrm{i}}$ - uniform tax rate for the Slovak republic for the i-th weight class for a vehicle not meeting Euro 3 (and more) emission limits and $1^{\text {st }}$ time not registered before 1990

$\mathrm{SN}_{1 \mathrm{i}}$ - uniform tax rate for the Slovak republic for the $\mathrm{i}$-th weight class for a vehicle $1^{\text {st }}$ time registered before 1990 $\mathrm{E}_{4 \mathrm{ij}}$ - number of Euro 4 (and more) taxable vehicles belonging to the i-th weight class and registered in the j-th region $\mathrm{E}_{3 \mathrm{ij}}$ - number of Euro 3 taxable vehicles belonging to the $\mathrm{i}$-th weight class and registered in the $\mathrm{j}$-th region

$\mathrm{O}_{\mathrm{ij}}$ - number of taxable vehicles, not meeting Euro 3 (and more) emission limits belonging to the i-th weight class and registered in the $\mathrm{j}$-th region

$\mathrm{S}_{3 \mathrm{ij}}$ - current tax rate for the $\mathrm{i}$-th weight class for vehicle of Euro 4 (or more) valid in the $\mathrm{j}$-th region

$\mathrm{S}_{2 \mathrm{ij}}$ - current tax rate for the i-th weight class for Euro 3 vehicle valid in the $\mathrm{j}$-th region

$\mathrm{S}_{1 \mathrm{ij}}$-current tax rate for the $\mathrm{i}$-th weight class for a vehicle not meeting Euro 3 (and more) emission limits valid in the $\mathrm{j}$ th region

$\mathrm{i}$ - class of the tax rate book depending on

$\mathrm{n}$ - the number of classes in the tax rate book (weight classes)

$\mathrm{j}$ - $\mathrm{j}$-th self - governing region, $\mathrm{j}=1-8$

Table 4 contains alternative results of modeling tax rates for individual categories of taxable commercial vehicles. It concerns the change in the rate for selecting more environmentally friendly vehicles, or non-ecological vehicles in respect to the base tax rate, so that it complies with in equation (1). 
Accurate data for the model could be obtained from the toll operator in Slovakia. It is due to the fact that the on-board units are required on all public roads in Slovakia for trucks with a gross weight over 3,5 tones and buses ${ }^{4}$.

Table 4. Alternative results of modeling tax rates for individual categories of taxable commercial vehicles in relation to the basic tax rate

\begin{tabular}{|c|c|c|c|c|}
\hline Variant & Basic tax rate & $\begin{array}{c}\text { Tax rate for Euro } 3 \\
\text { vehicles }\end{array}$ & $\begin{array}{c}\text { Tax rate for Euro } 4 \\
\text { (or more) vehicles }\end{array}$ & $\begin{array}{c}\text { Tax rate for vehicles } \\
\text { 1st time registered } \\
\text { before } 1990\end{array}$ \\
\hline I. & $100 \%$ & $-5 \%$ & $-10 \%$ & $+0 \%$ \\
\hline II & $100 \%$ & $-7,5 \%$ & $-15 \%$ & $+0 \%$ \\
\hline III & $100 \%$ & $-10 \%$ & $-20 \%$ & $+5 \%$ \\
\hline IV. & $100 \%$ & $-12,5 \%$ & $-25 \%$ & $+15 \%$ \\
\hline V. & $100 \%$ & $-15 \%$ & $-30 \%$ & $+20 \%$ \\
\hline VI. & $100 \%$ & $-20 \%$ & $-40 \%$ & $+35 \%$ \\
\hline VII. & $100 \%$ & $-25 \%$ & $-50 \%$ & $+50 \%$ \\
\hline
\end{tabular}

The proposed gradation of uniform tax rates is based on the gradation of tax rates applied for example in the Czech Republic, where it proved its worth in practice. Suggestions for the Slovak republic respect local characteristics (structure of the vehicle fleet, principles of taxation). According to the study (Gnap et al., 2012), a proposal of uniform tax rates and their gradation according to environmental (or age) principle would confirm the validity of inequality (1). The proposed uniform tax rates set at ecological principle would ensure tax revenues from motor vehicles tax at least at current level.

Tax revenues from motor vehicles tax should continue to serve self-governing regions to finance activities related to their competencies. The criteria for their objective redistribution between regions were also proposed in the study by authors (Gnap et al., 2012).

\section{Conclusion}

Implemented fiscal decentralization in the Slovak republic does not allow to achieve the objectives and principles of the tax reform concept in the motor vehicles tax area. Filling of the budgets of self - governing regions and financing their activities are also directly determined by the funds raised from motor vehicles tax. The tax rate as well as the range of exemptions is in the exclusive competency of self-governing regions. This negates the possibility to approximate the rates of motor vehicles tax to a level comparable with the recommended minimum tax rates (according to Directive 1999/62 / EC on the charging of heavy goods vehicles for the use of certain infrastructures) or with the average tax rate in European Union countries.

Frequent changes in tax rates well-grounded by the competency of self-governing regions create a climate of uncertainty in the area of vehicle taxation for the future. This uncertainty is multiplied by the increase in tax rates. The time of economic and technical life of road transport vehicles is significantly longer compared to the time of application of unchanged tax rates in specific regions. The solution is centrally determined tax rates with exactly defined criteria for its redistribution among self-governing regions. The trend in some European countries is to stabilize the tax system in the area of vehicle taxation even to the extent, where the tax rates are being reduced, for example in Austria (Greven, 2012, OECD, 2012).

Actually, revenue from the motor vehicles tax does not directly grow thanks to the fiscal decentralization. Fiscal decentralization provided a tool for self-governing regions to increase tax rates of vehicles. As a result, tax revenues of self-governing regions currently grow. The competence to impose a motor vehicles tax and to set tax rates by self-governing authorities at regional level may lead to a failure in achieving goals at the national level, for example in reducing environmental impacts and energy demands in the transport sector. Also, based on the results and recommendations of previous studies (Gnap et al., 2007, 2010, 2012), there was a success in bringing some of the ecology elements into the tax rates. Specifically, the self-governing regions of Banska Bystrica and Trnava applied a tax relief for articulated vehicles in 2014. Not only for the towing vehicle according to its emission limit, but also for the trailer based on the emission limit of the towing vehicle.

The results of expert studies by the authors (Gnap et al., 2007, 2010, 2012) were available for the preparation of the draft law on the motor vehicles tax from the position of the Ministry of Finance of the Slovak republic. The aim of the proposal was to tax motor vehicles more fairly. Motor vehicles tax rates

\footnotetext{
${ }^{4}$ The finding within the outcomes of Centre of excellence for systems and services of intelligent transport project, ITMS project code 26220120028
} 
for 2015 were reduced and consolidated at the level of the average rates set throughout the self - governing regions in 2014. The law is effective from 1 January 2015. The figure 5 depicts new annual tax rates and their time differentiation based on the time of the 1st registration of vehicle according to new Law no. $361 / 2014$ collection of laws, about motor vehicle tax. The figure 6 includes comparison between annual tax rates of motor vehicle tax in the Slovak republic in 2014 and 2015 for semi-trailer truck.

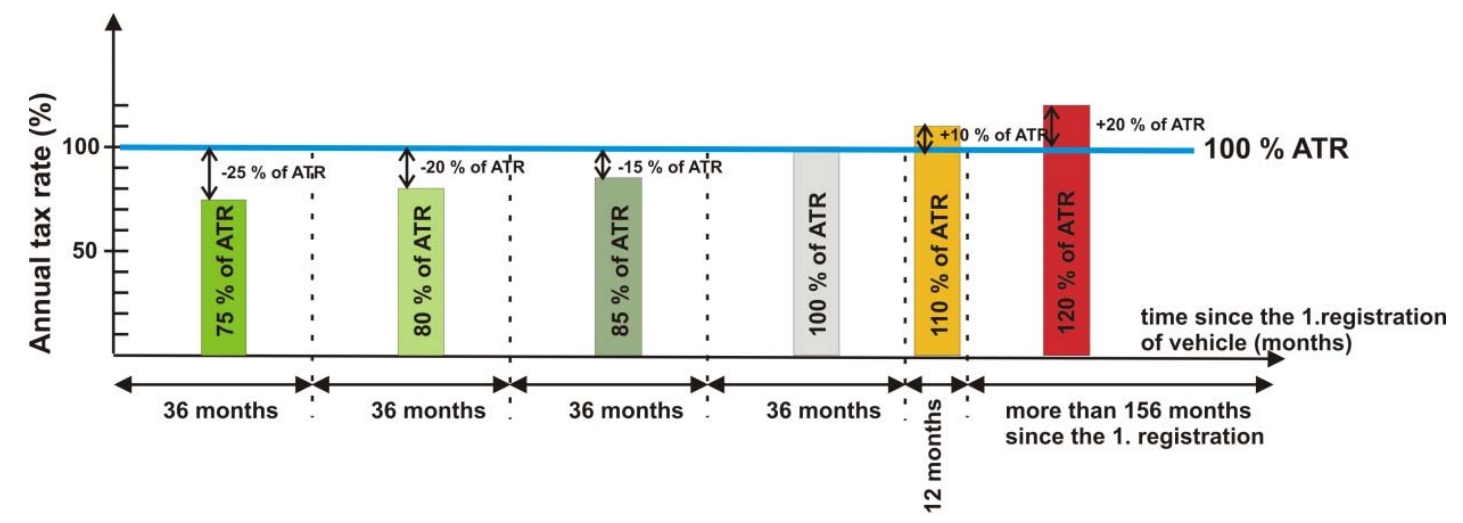

Figure 5. The annual tax rates (ATR) and time differentiation of ATR based on the time of the $1^{\text {st }}$ registration of vehicle according new law on motor vehicle tax
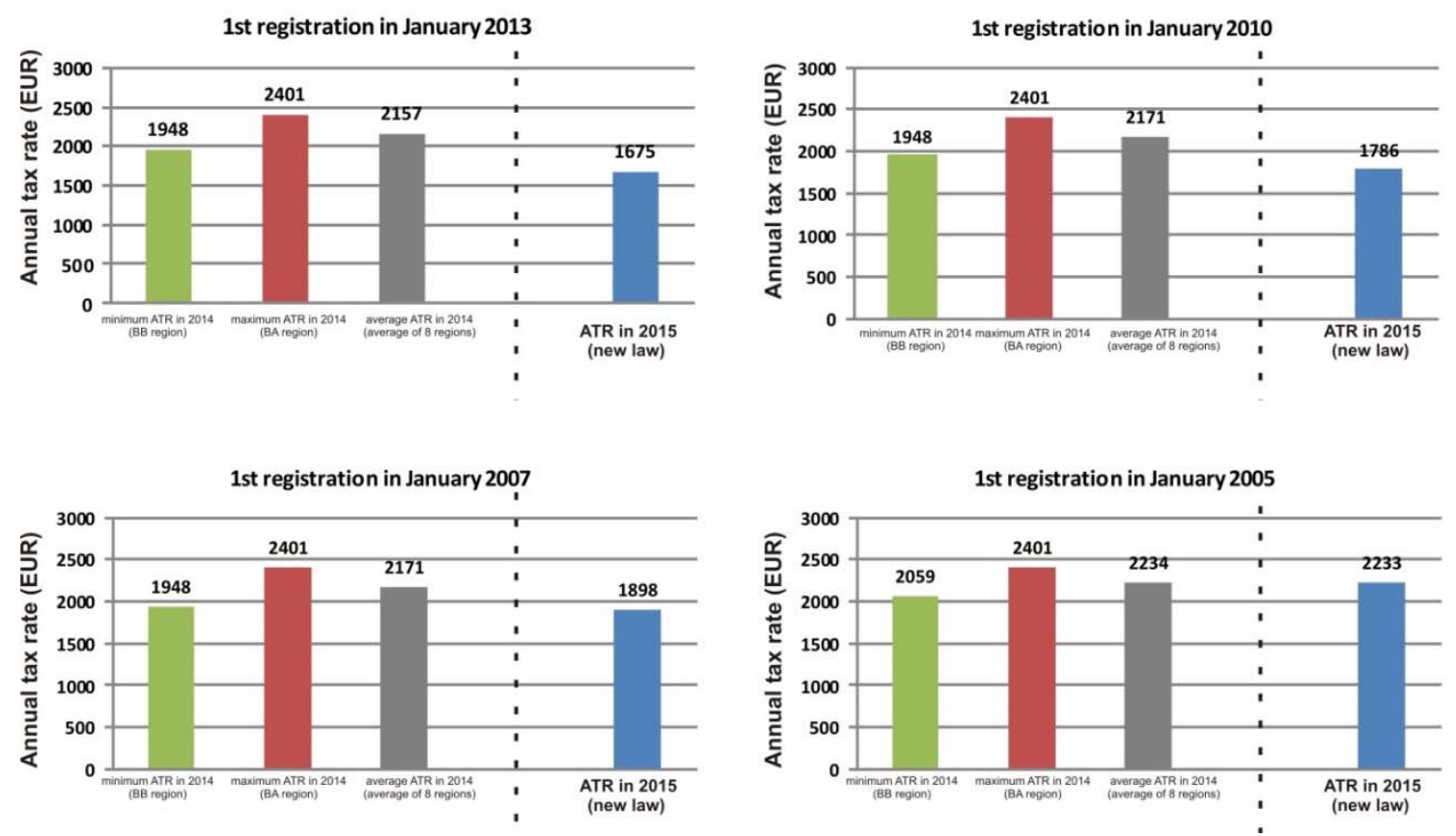

Figure 6. The comparison of ATR for semi-trailer truck in 2014 and 2015 (new law) in the Slovak republic

The research activities and results of studies of authors were used for changing and improvement of legislative on motor vehicle taxation in the Slovak republic.

\section{References}

1. ARISTOVNIK, A. (2012) Fiscal decentralization in Eastern Europe, a twenty-year perspective. Munich Personal RePEc Archive. <http://mpra.ub.uni-muenchen.de/39316/>.

2. BARBOUR, K. A., (2009) The Effects of Motor Vehicle Wealth Taxes on Households' Vehicle Purchase Decisions. Journal of Economics and Economic Education Research, Vol. 10. (No.3.). ISSN 1533-3604

3. Daňové riaditel'stvo SR. (2004) Výročná správa o činnosti daňových orgánov za rok 2004.

4. FELD, L.; et al. (2003) Decentralized taxation and the size of government: Evidence from Swiss States and local governments, CESifo Working Paper 1087. 
5. GNAP, J. (2006) Kalkulácia vlastných nákladov a tvorba ceny v cestnej deprave. Žilina: EDIS vydavatel'stvo Žilinskej univerzity. Žilina, 2006. ISBN 80-8070-608-5.

6. GNAP. J. ; KONEČNÝ, V et al. (2007) Daň z motorových vozidiel a environmentálna prijatel'nost' vozidiel cestnej dopravy v SR. Žilina: Žilinská univerzita v Žiline, 2007

7. GNAP. J. et al. (2008) Fiškálna decentralizácia a zmeny v legislatíve SR a EÚ a jej vplyv na financovanie a kvalitu hromadnej osobnej dopravy v SR. Žilina: Žilinská univerzita v Žiline, 2008, project VEGA č.1/3786/06. 2008

8. GNAP. J. ; KONEČNÝ, V et al. (2010) Daň z motorových vozidiel v SR. Žilina: Žilinská univerzita v Žiline, 2010

9. GNAP. J. ; KONEČNÝ, V et al. (2012) Daň z motorových vozidiel v SR. Žilina: Žilinská univerzita v Žiline, 2012

10. GREVEN, M. (2011) Tax Guide 2011. ACEA - European Automobile Manufacturer's Association. $<\mathrm{http}$ //www.acea.be/collection/taxation_publications $>$.

11. GREVEN, M. (2012) Tax Guide 2012. 2012. ACEA - European Automobile Manufacturer's Association.

12. Ministerstvo financií SR (2005) Koncepcia daňovej reformy pre roky 2004-2006.

13. KONEČNÝ, V.: Dan̆ z motorových vozidiel. Truck and Business. 2013. Vol. 6 (No.2.) pp. 32-33. ISSN 1337-897X

14. KOZOVSKÝ, D. (2007) Fiškálna decentralizácia a jej vplyv na vybrané makroekonomické indikátory. Ekonomický časopis, Vol. 54 (No.10.) pp. 1037-1052. ISSN 0013-3035

15. KOZOVSKÝ, D. - ŽÁRSKA (2009), E.: Miera decentralizácie a rozpočty územných samospráv s aplikáciou na slovenské podmienky. Katedra veřejných financí, Vysoká škola ekonomická v Praze, apríl 2009, $21 \mathrm{~s}$.

16. KRÁLOVENSKÝ, J. et al. (2008) Ekonomika cestnej a mestskej dopravy. Žilina: EDIS vydavatel'stvo Žilinskej univerzity. Žilina, 2008. ISBN 978-80-8070-831-5

17. MAJERSKÝ, R. (2004) The Process of Fiscal Decentralization. State Budget Department, Ministry of finance Slovak Republic.

18. MASARYK, P. (2014) Ako využívame výnos vybranej dane z motorových vozidiel. Kilometer: informačný spravodajca Združenia cestných dopravcov Slovenskej republiky, Vol. 22, (No.6.) pp. 1617, ISSN 1335-9894

19. NEUPAUEROVÁ, Z. (2008) Regionálne rozdiely ako možné riziko fiškálnej decentralizácie. In: Financie a riziko, zborník príspevkov z X. ročnika medzinárodnej vedeckej konferencie. Bratislava, Vydavatel'stvo EKONÓM.

20. NIŽŇANSKÝ, V. (2005) Decentralizácia na Slovensku: bilancia nekonečného príbehu 1995-2005. Považská tlačiareň. 2006. ISBN 80-7179-748-0.

21. NIŽŇANSKÝ, V. - VALENTOVIČ, M. (2002) Financovanie samosprávy VÚC od roku 2004. M.E.S.A. 10. Bratislava. 2002.

22. OATES, W. E. (1972) Fiscal federalism. New York: Harcourt Brace Jovanovich.

23. OECD (2012) Consumption Tax Trends 2010. VAT/GST and Excise Rates, Trends and Administration Issues. Chapter 6 - Taxing Vehicles. 2012. ISBN 978-92-64-18218-9

24. PÉTROVÁ, R. (2007) Fiškálna decentralizácia a jej vplyv na výšku nákladov miestnych Samosprávnych celkov. In. Zborník príspevkov z 12. medzinárodnej konferencie „, Theoretical and Practical Aspects of Public Finance. Vysoká škola ekonomická v Prahe. Praha 2007. ISBN 80-2451032-4.

25. RODRÍGUEZ-POSE, A. - KRǾIJER, A. (2009) Fiscal Decentralization and Economic Growth in Central and Eastern Europe. LEOS Paper No. 12/2009. London School of Economics. London, 2009.

26. SPORINA, J. (2012) Zdaňovanie motorových vozidiel. Inštitút finančnej politiky MF SR. 2012.

27. ŠIKULA, M. et al. (2008) Dlhodobá vizia rozvoja slovenskej spoločnosti. Ekonomický ústav Slovenskej akadémie vied. Bratislava. 2008. ISBN 978-80-7144-168-7

28. ŠIMOŇÁKOVÁ, E. (2011) Financovanie samosprávnych krajov SR, In.: Zborník z konferencie: Združenie SK8 a Stála konferencia organizácií tretieho sektora Slovenskej republiky, Trnava, 27.10.2011, Úrad Trnavského samosprávneho kraja.

29. Štatistický úrad SR. (2011) Ročenka dopravy, pôšt a telekomunikácií SR 2011. ISBN 978-80-8121091-4

30. Štatistický úrad SR. (2013) Ročenka dopravy, pôšt a telekomunikácií SR 2013. ISBN 978-80-8121255-0

31. The output from the project of Excellence Centre for systems and intelligent transport (2012) ITMS project code 26220120028, University of Žilina in Žilina, 2012. 